\title{
Impacts of Planners' Different Viewpoints on Optimum Land-Use Allocation
}

\author{
ERSIN TÜRK* \& HÜSEYIN MURAT ÇELIK** \\ *Department of City and Regional Planning, Karadeniz Technical University, Trabzon, Turkey ** Department \\ of City and Regional Planning, Izmir Institute of Technology, Urla Izmir, Turkey
}

(Received November 2011; accepted April 2012)

\begin{abstract}
Development of different viewpoints/perspectives in the planning process and discussion of their empirical results will allow creation of "better land-use plans". In this sense, one of the deficiencies met by the land-use planners is lack of decision support system that can analyse the empirical results of different viewpoints analytically. The aim of this study is to analyse impacts between planners' different viewpoints and the optimum land-uses allocation empirically and analytically. The study uses a generalized land assignment model formulated by Hanink and Cromley (1998) [Land-use allocation in the absence of complete market values, Journal of Regional Science, 38(3), pp. 465-480] that integrates the geographical information systems with multi-criteria decision-making techniques in Cesme/Izmir in Turkey. The study results indicated that the model is very useful to analyse impacts between planners' viewpoint and optimum land-use allocation.
\end{abstract}

\section{Introduction}

Planning is a career field which requires group work due to its scale and scope. However, the land-use plans, which are end products, emerge as a result of certain design rules and criteria taken into consideration by the project coordinator. But during the planning process, each planners' design criteria, threshold values and weights given to each factor differs from each other. Accordingly, development of decision support systems to analyse possible results of different alternatives will allow both the emergence of better plans and a participatory planning process, via opening up the possible results of alternatives for discussion. In this context, the primary aim of this study is to analyse the relationship between the planners' different points of view and the optimum land-use allocation. The secondary aim is to develop a decision support system which will help to analyse the

Correspondence Address: Ersin Türk, Department of City and Regional Planning, Karadeniz Technical University, Trabzon, Turkey. Email: ersinturk@iyte.edu.tr 
results, if there were several alternatives/scenarios produced during the planning process. Generalized Land Assignment Model (Hanink \& Cromley, 1998) is used in the empirical study.

In previous years, advances in computers and information technology paved the way for the production of analytical tools that could be used in the analysis of the planning and spatial decision-making problems with the integration of Geographical Information Systems (GIS) and Multi-criteria Decision-Making (MCDM) methods. The main strategy of the MCDM technique is to divide the problem into small and comprehensible pieces, analyse each piece and provide a meaningful/reasonable solution to the problem by bringing the pieces together in a logical way (Malczewski, 1999).

MCDM techniques integrated with the GIS have been widely used since the year 1980, especially in solving problems of resource distribution in the fields of environment/ ecology, transportation, urban/regional planning, waste management, hydrology, agriculture and forestry (Malczewski, 2006a). MCDM techniques are classified into two groups; "Multi-criteria Analysis (MCA)" and "Multi-Objective Decision Analysis (MODA)". MCA techniques are used in the preparation of a land suitability evaluation map for a given land use/s or facility (Pereira \& Duckstein, 1993; Malczewski, 1996, 2006b; Dai et al., 2001; Joerin et al., 2001; Banai, 2005; Natividade-Jesus et al., 2007), and in the evaluation and selection of the predetermined and limited number of allocation alternatives (Carver, 1991; Bodini \& Giavelli, 1992; Zucca et al., 2007). MCA is a very simple and a useful evaluation and selection technique if alternatives are predetermined and limited in numbers. On the contrary, MODA is useful in the determination of the optimum alternative when the alternatives are indefinite or unlimited. The use of MODA is widespread in a number of planning-related areas such as the definition of the optimum land allocation model (Bammi \& Bammi, 1979; Gilbert et al., 1985; Chuvieco, 1993; Dokmeci et al., 1993; Grabaum \& Meyer, 1998; Gabriel et al., 2006; Ligmann-Zielinska et al., 2008), site selection of urban social and technical infrastructure (Malczewski, 1991; Minor \& Jacobs, 1994; Eastman et al., 1995; Maniezzo et al., 1998; Cheng et al., 2003), land allocation problems with a shape constraint such as compactness (Aerts \& Heuvelink, 2002; Aerts et al., 2003); convexity and contiguity (Minor \& Jacobs, 1994; Williams, 2003; Shirabe, 2005) and the environmental impact assessment (Malczewski et al., 1997). MODA is a design technique which determines the optimum solution or the best alternative.

Generalized Land Assignment Model has the potential to be an analytical tool that can solve most of the current problems encountered by decision-makers and land-use planners. Possible usage of the model can be the determination of level of land uses, location selection of facilities and redefinition of the standards of social and technical infrastructure areas. This model is theoretically based on the Von Thünen Model and technically on the MODA. Formulated as a binary integer programming, the model assumes the city as consisting of equal sized cells (raster parcels) and assigns a land use for each parcel according to the suitability score instead of the monetary value. The use of the suitability score instead of the real market value makes it possible to include social and environmental benefits besides the economic benefits of different land-use types. Hanink and Cromley (1998) applied this model to the three generic land uses on a hypothetic piece of land. Moreover, Çelik and Türk (2011) used the same model to determine an optimum level of the conservation scheme in Cesme/Izmir. 


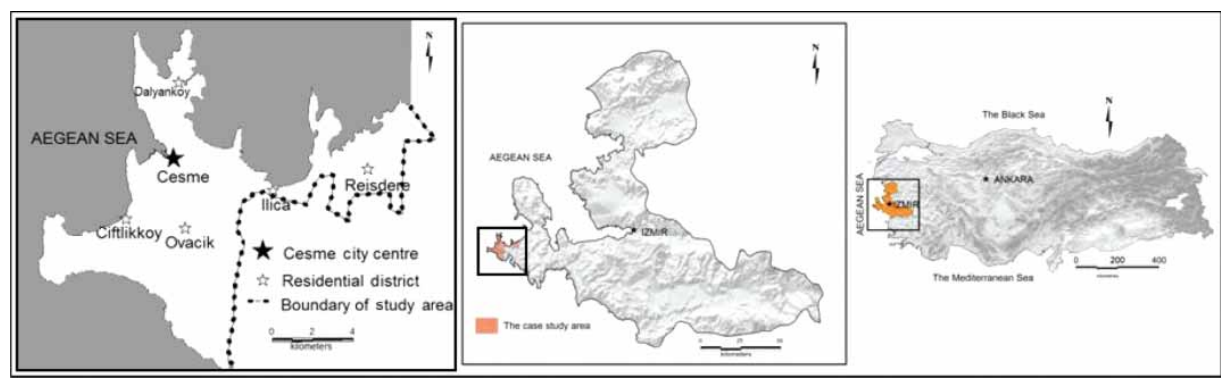

Figure 1. Study area.

The case study area, Cesme, is a small town on the Aegean Coast of Turkey (Figure 1). The Cesme peninsula has become a national and international tourism destination, taking its share from the rapid growth in the Turkish tourism sector beginning from the year 1980. This rapid growth in the tourism sector put a development pressure on the Cesme Peninsula, which acquires many important natural and archaeological assets. The shift in the balance of power, from environmentalist groups to entrepreneurs and the political atmosphere of the era have led to the change of the conservation scheme six times and land-use plans four times between the years 1991 and 2012. As a result, the land-use plan decisions have been subject to debate/conflict, because they are not established via a procedure which entails the participation and consensus of all stakeholders. This study is expected to contribute to the development of decision support systems in the analysis of different viewpoints and site selection decisions and amount of land allocation for different land-use types.

The Delphi method was used in the data preparation stage. Twenty city planners participated in the definition of the criteria to be used in the site selection of each land use. Two academicians from the City and Regional Planning Department of the İzmir Institute of Technology (IYTE) previously prepared the Cesme 1/25,000 Scale Land-Use Plan in 2002 and also two planners from a private planning bureau which prepared the 1/100,000 scale Manisa-Kütahya-İzmir Regional Plan in 2007 and the Cesme 1/25,000 Scale Revised Land-Use Plan in 2010 participated in the empirical study. However, the administrative court of Izmir has stopped the execution of the Cesme 1/25,000 Scale Revised Land-Use Plan in 2011.

The next section explains the technique used in the study. The description of the study area is presented in the third section. The Forth section four is devoted to the explanation about data preparation. The fifth section explains the results, and the final section concludes the article.

\section{Generalized Land Assignment Model}

Generalized Land Assignment Model is a mathematical programming which is integrated into the MCDM and GIS techniques. The first phase of the model consists of the preparation of the required data. In order to obtain the required data, the composite suitability index, $S_{i j}$, of every parcel for each land-use type should be calculated by using MCDM techniques. The suitability score of every parcel is defined by the site and situation factors of the parcel. While site factors contain the criteria related to the attributes of the parcel, situation factors contain the criteria related to the accessibility or distance of the parcel. Saaty (1980) suggests the utilization of the Analytical Hierarchy Process 
(AHP) in order to determine the weights of the criteria $\left(w_{i j k}\right)$. Eigenvector of the pair-wise comparison matrix forms the weights of criteria. Considering the fact that the city consists of thousands of parcels, it is necessary to use MCDM techniques that can be integrated into GIS techniques to define the composite suitability index $S_{i j}$ of every parcel. GIS enables both the preparation of required maps and the formation of the required data base. After the definition of suitability index of each parcel in terms of every criterion, the combined suitability weight is calculated by using equation (1):

$$
S_{i j}=\sum_{k=1}^{P_{j}} w_{i j k} A_{i j k}^{\prime} \quad \forall i, j,
$$

where $S_{i j}$ is the composite suitability index, $P_{j}$ is the number of criteria for the $j$ th land use, $w_{i j k}$ is the weight of the $k$ th criterion with respect to the $j$ th potential land use for the $i$ th parcel and $A_{i j k}^{\prime}$ is the suitability scalar of the $i$ th parcel for the $j$ th land use with respect to the $k$ th criterion.

The model is based on the Von-Thünen Model. With the Von-Thünen Model (Hall, 1966), urban land-use distribution was modelled by taking transportation costs as the basis. According to this model, while competitive land-use types are chosen to be located in the city centre, other land-use types are located in the periphery and their exact locations are determined according to the land rents. Therefore, there are differences among the urban land uses and in order for the most important land use to be assigned to the most suitable parcels; their trade-off values should be known. Trade-off values have been calculated by using the pair-wise comparison technique and for the suitability scores to be within the same interval, combined suitability scores were normalized. Suitability score of each parcel was calculated by using the second equation (Hanink \& Cromley, 1998; Malczewski, 1999):

$$
S_{i j}^{\prime}=W_{j} \frac{S_{i j}-\min _{i} S_{i j}}{\max _{i} S_{i j}-\min _{i} S_{i j}} .
$$

The model is formulated as a binary integer programming. The model which assumes the city consisting of equal sized grids, assigns only one land use to each parcel depending on the suitability score of that land use. The purpose of this model is to obtain the optimum land-use allocation in order to maximize the total benefit. The model is mathematically expressed as given below (Hanink \& Cromley, 1998):

$$
\begin{gathered}
\text { Maximize: } \quad \sum_{i=1}^{n} \sum_{j=1}^{m} S_{i j}^{\prime} X_{i j} \\
\text { Subject to: } \quad \sum_{j=1}^{m} X_{i j} \leq 1, \\
\sum_{i=1}^{n} X_{i j}=D_{j}, \\
X_{i j}=0 \quad \text { or } \quad 1 \forall i, j,
\end{gathered}
$$

where $n$ is the number of land parcels, $m$ is the number of land uses, $X_{i j}$ is the decision variable assigning the $i$ th land parcel to the $j$ th land use, $S_{i j}^{\prime}$ is a suitability measurement 
of the parcel $i$ when it is assigned to the $j$ th land use and $D_{j}$ is the demand level for the $j$ th land use.

Equation (4) assigns only one land use for each parcel among $m$ land-use types. Because in this study, it is assumed that land uses are in competition with each other and only one land-use type can exist within a parcel. Equation (5) guarantees that the total number of parcels that is assigned for each land-use type is equal to predetermined number of parcels. Equation (6) guarantees that every decision variable is binary. The dual formulation of this programme can be expressed as (Hanink \& Cromley, 1998):

$$
\begin{aligned}
& \text { Minimize: } \quad \sum_{j=1}^{m} D_{j} C_{j}+\sum_{i=1}^{n} R_{i} \\
& \text { Subject to: } \quad C_{j}+R_{i} \geq S_{i j}^{\prime} \quad \forall i, j,
\end{aligned}
$$

where $C_{j}$ is the shadow price associated with the demand for each land use and $R_{i}$ is the shadow price associated with the demand for each parcel.

The shadow price refers to the increase in the value of the objective function when the source is increased by one unit. Barr (1973) interpreted $R_{i}$ as an ideal market price and $C_{j}$ as the total urban benefit. Hanink and Cromley (1998) suggested that the approximate

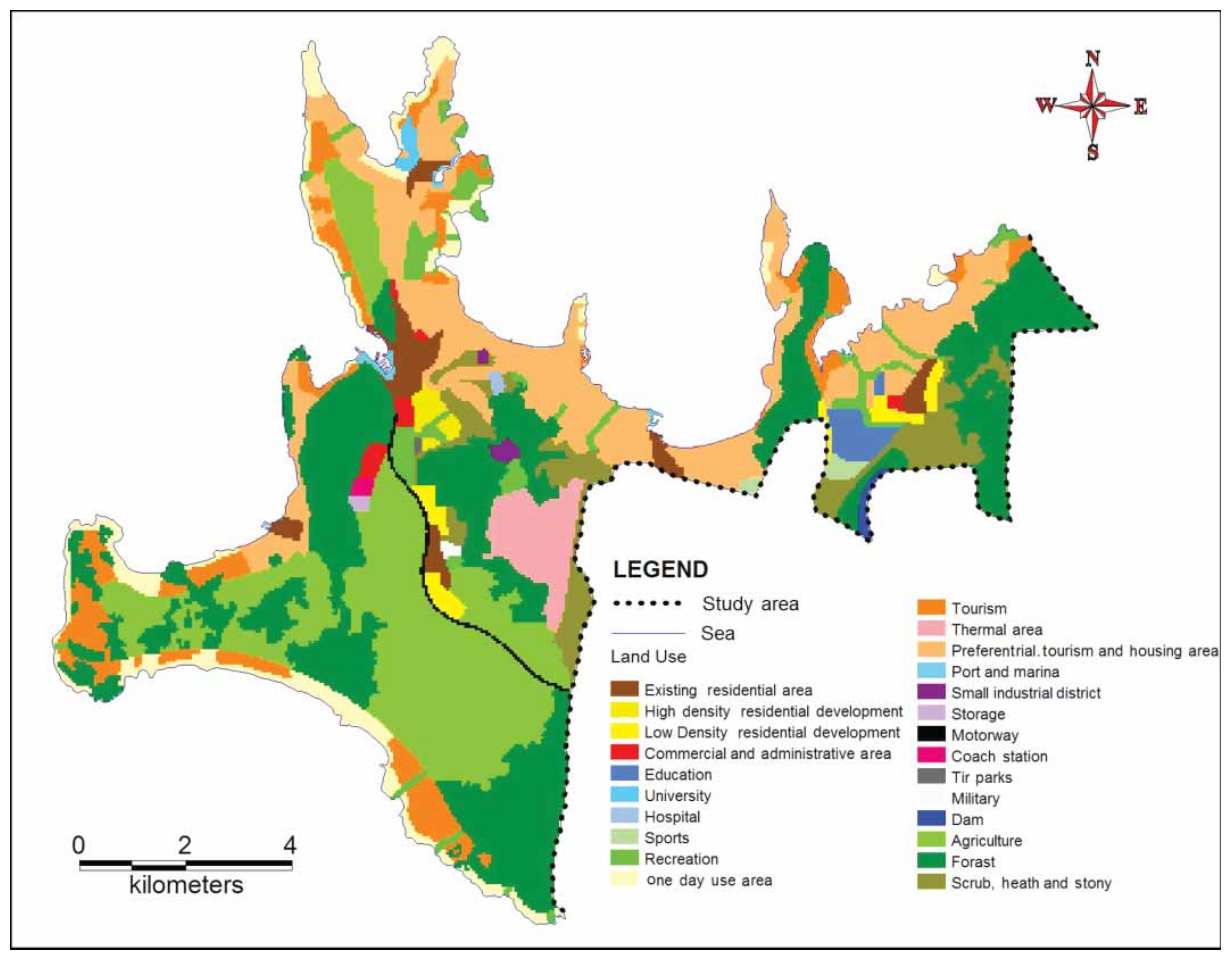

Figure 2. 1/25,000 Scale Cesme Land-Use Plan, 2002. 
Table 1. Future land-use amounts and corresponding number of grid parcels

\begin{tabular}{lcc}
\hline Land-uses & Area (ha) & No. of parcels \\
\hline Residential development area & 184 & 735 \\
Commerce and administrative area & 105 & 419 \\
Tourism area & 680 & 2716 \\
Preferential tourism and residential & 1644 & 6576 \\
Thermal tourism & 279 & 1116 \\
Public facilities & 106 & 424 \\
Recreation area & 891 & 3564 \\
Agricultural area & 1887 & 7548 \\
Forestation & 2762 & 11,048 \\
Unusable areas & 531 & 2124 \\
Total & 9068 & 36,270 \\
\hline
\end{tabular}

price of land uses of which market price is unknown could be calculated by using the ratio of the shadow price value to monetary value of land uses having the market price.

\section{Study Area}

The study area covers the Cesme 1/25,000 Scale Land-Use Plan boundaries which encloses part of the Cesme Peninsula located in the far west corner of the İzmir Province, and has 9450 ha surface area (Figure 1). Cesme is an important summer resort of Turkey for the nationals and a very attractive destination for international tourists. For this reason, the city's population increases substantially in summers. While the population of the city is around 30,000 in winters, it rises up to 150,000 and even to 200,000 at weekends in summer seasons.

The determination of land-use types and their surface areas were based on the land-use distribution of the Cesme 1/25,000 Scale Land-Use Plan (Figure 2) prepared by City and Regional Planning Department of IYTE in 2002 (Office of Revolving Funds) (Table 1). Nine different classes were formed out of 24 different land uses existing in this plan, because the pair-wise comparison technique can consistently compare only $7 \pm 2$ alternatives (Saaty, 1980). In total, 382 ha of the existing built-up area and technical infrastructure areas were not included in this model. The total area included in this study is 9068 ha. Population projection of the plan is 180,000 .

\section{Preparation of Required Data Base}

In order to obtain the required data base, two different studies were carried out. The first one is to conduct the required survey and questionnaires to determine (i) the suitability evaluation criteria for each land use by using the Delphi method (ii) the combination weights of criteria for each land use by using AHP and (iii) the trade-off weights for each land use by using AHP. The second study is the preparation of digital thematic maps that represents the evaluation criteria in the model.

First, a survey was conducted o define the site selection criteria affecting each land use. Twenty city planners familiar with the Cesme from universities, municipalities and provincial directorates of the Ministry of Construction of Izmir participated in the survey. 
According to the Delphi method, the survey was conducted in two stages. In the first stage, a questionnaire including the potential criteria which would affect the site selection of each land use was mailed to the planners and they were asked to score the relevance of each criterion to each land use between 1 and 5 according to the effect of that criterion in the site selection of that land use. " 1 " implies that the related criterion is not important for that land-use type and 5 implies that the criterion is very important. In the second stage, descriptive statistics of the first-stage questionnaire and an analysis were sent to the participants, and they were asked to revise their previous answer in accordance with the results of the first stage if they wanted. Their revised answers in the second stage were statistically analysed. A criterion with a mean value equal to or higher than 3 was deemed as important for the respective land use (Table 2).

As a result of this survey, slope, ownership of property (i.e. private versus public), quality of the soil for agricultural use, geological structure, conservation degree, existing land use, aspect of the land, visibility of the sea and location with respect to existing potable water dam were determined as important site factors. Among them, only the quality of the soil appeared to be important for all land uses. Concerning situational factors, proximity to a highway, to a second road, to Cesme city centre, to a residential district, to the sea, to a beach, to a thermal spring and distance to a fault was found to be the relevant accessibility factors. The selected criteria and their relevance to the land uses are presented in Table 2.

The next stage is to define the combined weights of each criteria used in the first formula for each land-use type. Two academicians from the IYTE who prepared the Cesme 1/25,000 Scale Land-Use Plan in the year 2002 and two planners from the private planning bureau who prepared the 1/100,000 scale Manisa-Kütahya-İzmir Regional Plan in 2007 and the Cesme 1/25,000 Scale Revised Land-Use Plan in 2010 took part in this study in which the pair-wise comparison technique was used. Annex 2 provides the weights of each criterion for each land use. These weights were formed according to the scores assigned by the participants.

The last necessary information was the trade-off weights of each land use. Trade-off weights were used to allocate important land uses to more suitable parcels. Thus, rather than being a technical necessity, this operation served the aim of defining the relative importance of land uses, depending on the planner's viewpoint. The four planners taking part in the plan preparation process were first asked to make pair-wise comparisons of the environmental, social and economic benefit, using the Analytic Hierarchy Process (AHP) and their second task was to make the pair-wise comparisons of each land-use type with other land uses for each of the three benefits. As a result of the AHP (Table 3):

- The first planner expressed that the economic benefit and environmental benefits are equivalent and those are more important than the social benefit. In total, the planner gave the highest trade-off weights to thermal tourism and tourism and the lowest trade-off weights to preferential tourism and residence and public establishment areas.

- The benefits were ranked according to the weights given by the second planner as social, environmental and an economic benefit. In total, land uses which have the highest trade-off weights are thermal tourism and recreation, and land uses which have the lowest trade-off weights are residential development, commercial and administrative areas. 
Table 2. Selection of evaluation criteria

\begin{tabular}{|c|c|c|c|c|c|c|c|c|c|}
\hline & $\begin{array}{l}\text { Residential } \\
\text { development }\end{array}$ & $\begin{array}{l}\text { Commerce and } \\
\text { administrative }\end{array}$ & Tourism & $\begin{array}{c}\text { Preferential } \\
\text { tourism and } \\
\text { residential }\end{array}$ & $\begin{array}{l}\text { Thermal } \\
\text { tourism }\end{array}$ & $\begin{array}{c}\text { Public } \\
\text { establishment }\end{array}$ & Recreation & Agricultural & Forestation \\
\hline \multicolumn{10}{|l|}{ Site factors } \\
\hline Slope & $\checkmark$ & $\checkmark$ & $\checkmark$ & $\checkmark$ & $\checkmark$ & $\checkmark$ & & & \\
\hline $\begin{array}{l}\text { Ownership of } \\
\text { property }\end{array}$ & $\checkmark$ & $\checkmark$ & $\checkmark$ & $\checkmark$ & $\checkmark$ & $\checkmark$ & $\checkmark$ & & $\checkmark$ \\
\hline Quality of soil & $\checkmark$ & $\checkmark$ & $\checkmark$ & $\checkmark$ & $\checkmark$ & $\checkmark$ & $\checkmark$ & $\checkmark$ & $\checkmark$ \\
\hline $\begin{array}{l}\text { Geological } \\
\text { structure }\end{array}$ & $\checkmark$ & $\checkmark$ & $\checkmark$ & $\checkmark$ & $\checkmark$ & $\checkmark$ & & & \\
\hline $\begin{array}{l}\text { Conservation } \\
\text { degree }\end{array}$ & $\checkmark$ & $\checkmark$ & $\checkmark$ & $\checkmark$ & $\checkmark$ & $\checkmark$ & $\checkmark$ & & $\checkmark$ \\
\hline Existing land use & $\checkmark$ & $\checkmark$ & $\checkmark$ & $\checkmark$ & $\checkmark$ & $\checkmark$ & $\checkmark$ & $\checkmark$ & $\checkmark$ \\
\hline Aspect & $\checkmark$ & & $\checkmark$ & $\checkmark$ & $\checkmark$ & & $\checkmark$ & & \\
\hline Visibility of sea & $\checkmark$ & & $\checkmark$ & $\checkmark$ & & & $\checkmark$ & & \\
\hline $\begin{array}{l}\text { Location w.r.t. } \\
\text { potable water dam }\end{array}$ & $\checkmark$ & $\checkmark$ & $\checkmark$ & $\checkmark$ & $\checkmark$ & $\checkmark$ & $\checkmark$ & & \\
\hline \multicolumn{10}{|l|}{ Situation factors } \\
\hline $\begin{array}{l}\text { Proximity to } \\
\text { highway }\end{array}$ & $\checkmark$ & $\checkmark$ & $\checkmark$ & $\checkmark$ & & $\checkmark$ & & & \\
\hline $\begin{array}{l}\text { Proximity to second } \\
\text { degree road } \\
\text { Proximity to } \\
\text { motorway entrance }\end{array}$ & $\checkmark$ & $\checkmark$ & $\checkmark$ & $\checkmark$ & $\checkmark$ & $\checkmark$ & & & \\
\hline $\begin{array}{l}\text { Proximity to Cesme } \\
\text { city centre }\end{array}$ & $\checkmark$ & $\checkmark$ & & $\checkmark$ & & $\checkmark$ & & & \\
\hline $\begin{array}{l}\text { Proximity to } \\
\text { residential district }\end{array}$ & $\checkmark$ & $\checkmark$ & & & & $\checkmark$ & & & \\
\hline Proximity to sea & $\checkmark$ & & $\checkmark$ & $\checkmark$ & & & $\checkmark$ & & \\
\hline Proximity to beach & $\checkmark$ & & $\checkmark$ & $\checkmark$ & & & & & \\
\hline $\begin{array}{l}\text { Proximity to } \\
\text { thermal spring }\end{array}$ & & & $\checkmark$ & & $\checkmark$ & & & & \\
\hline $\begin{array}{l}\text { Distance to fault } \\
\text { line }\end{array}$ & $\checkmark$ & $\checkmark$ & $\checkmark$ & $\checkmark$ & $\checkmark$ & $\checkmark$ & & & \\
\hline
\end{tabular}


Table 3. Trade-off weights

\begin{tabular}{|c|c|c|c|c|c|c|c|c|c|c|c|c|c|c|c|c|}
\hline & \multicolumn{4}{|c|}{ First planner } & \multicolumn{4}{|c|}{ Second planner } & \multicolumn{4}{|c|}{ Third planner } & \multicolumn{4}{|c|}{ Fourth planner } \\
\hline & $\begin{array}{c}\text { Economic } \\
\text { benefit }\end{array}$ & $\begin{array}{l}\text { Social } \\
\text { benefit }\end{array}$ & $\begin{array}{l}\text { Environmental } \\
\text { benefit }\end{array}$ & $\begin{array}{l}\text { Trade- } \\
\text { off } \\
\text { weight }\end{array}$ & $\begin{array}{l}\text { Economic } \\
\text { benefit }\end{array}$ & $\begin{array}{l}\text { Social } \\
\text { benefit }\end{array}$ & $\begin{array}{l}\text { Environmental } \\
\text { benefit }\end{array}$ & $\begin{array}{l}\text { Trade- } \\
\text { off } \\
\text { weight }\end{array}$ & $\begin{array}{l}\text { Economic } \\
\text { benefit }\end{array}$ & $\begin{array}{l}\text { Social } \\
\text { benefit }\end{array}$ & $\begin{array}{l}\text { Environmental } \\
\text { benefit }\end{array}$ & $\begin{array}{c}\text { Trade- } \\
\text { off } \\
\text { weight }\end{array}$ & $\begin{array}{l}\text { Economic } \\
\text { benefit }\end{array}$ & $\begin{array}{l}\text { Social } \\
\text { benefit }\end{array}$ & $\begin{array}{l}\text { Environmental } \\
\text { benefit }\end{array}$ & $\begin{array}{l}\text { Trade- } \\
\text { off } \\
\text { weight }\end{array}$ \\
\hline $\begin{array}{l}\text { Land use/ criterion } \\
\text { weight }\end{array}$ & 0.43 & 0.14 & 0.43 & & 0.16 & 0.54 & 0.30 & & 0.23 & 0.08 & 0.69 & & 0.63 & 0.19 & 0.17 & \\
\hline $\begin{array}{l}\text { Residential } \\
\text { development }\end{array}$ & 0.09 & 0.07 & 0.03 & 0.07 & 0.09 & 0.02 & 0.02 & 0.03 & 0.21 & 0.03 & 0.03 & 0.06 & 0.08 & 0.09 & 0.05 & 0.08 \\
\hline $\begin{array}{l}\text { Commerce and } \\
\text { administrative }\end{array}$ & 0.24 & 0.03 & 0.03 & 0.13 & 0.17 & 0.09 & 0.02 & 0.08 & 0.10 & 0.08 & 0.06 & 0.07 & 0.18 & 0.21 & 0.03 & 0.16 \\
\hline Tourism & 0.24 & 0.03 & 0.09 & 0.15 & 0.24 & 0.12 & 0.11 & 0.13 & 0.10 & 0.08 & 0.09 & 0.09 & 0.26 & 0.03 & 0.02 & 0.18 \\
\hline $\begin{array}{l}\text { Preferential } \\
\text { tourism and } \\
\text { residence }\end{array}$ & 0.09 & 0.03 & 0.03 & 0.06 & 0.15 & 0.09 & 0.07 & 0.09 & 0.35 & 0.03 & 0.02 & 0.08 & 0.18 & 0.03 & 0.05 & 0.13 \\
\hline Thermal tourism & 0.24 & 0.26 & 0.17 & 0.21 & 0.27 & 0.15 & 0.16 & 0.16 & 0.10 & 0.16 & 0.09 & 0.10 & 0.21 & 0.08 & 0.12 & 0.17 \\
\hline $\begin{array}{l}\text { Public } \\
\text { establishment }\end{array}$ & 0.02 & 0.26 & 0.03 & 0.06 & 0.02 & 0.15 & 0.02 & 0.10 & 0.03 & 0.22 & 0.08 & 0.09 & 0.02 & 0.30 & 0.04 & 0.07 \\
\hline Recreation & 0.02 & 0.26 & 0.17 & 0.11 & 0.02 & 0.15 & 0.20 & 0.15 & 0.04 & 0.22 & 0.16 & 0.15 & 0.03 & 0.22 & 0.21 & 0.09 \\
\hline Agricultural & 0.03 & 0.03 & 0.28 & 0.13 & 0.03 & 0.12 & 0.20 & 0.13 & 0.04 & 0.10 & 0.25 & 0.20 & 0.03 & 0.03 & 0.21 & 0.06 \\
\hline Forestation & 0.02 & 0.07 & 0.17 & 0.08 & 0.02 & 0.12 & 0.20 & 0.13 & 0.03 & 0.08 & 0.23 & 0.18 & 0.02 & 0.02 & 0.26 & 0.06 \\
\hline
\end{tabular}


- The third planner expressed that the environmental benefit is very important in that scale and as a result of paired comparison ranked the benefits according to the importance as environmental, economic and social benefit. The planner assigned the highest trade-off weights to agriculture and forestation areas and the lowest tradeoff weights to residential development, commerce and administrative areas.

- The fourth planner ranked the benefits according to the importance as economic, social and environmental benefit. The planner assigned the highest trade-off weights to tourism and thermal tourism areas and the lowest trade-off weights to agriculture and forestation areas.

Most of the maps and information needed for the data base were obtained from the archives of the City and Regional Planning Department of the IYTE and the Cesme Municipality. Thematic maps were obtained from the archives and were digitized by using MapInfo software. Currently, GIS programmes do not have the capacity to analyse whether a parcel has the sea view or not totally. To make this analysis, a code was written using $\mathrm{C}++$; with this code, each parcel in the study area could be analysed with respect to sea view, and then thematic maps were formed. Afterwards, all digitized vector maps were transformed into raster maps as the database. Each grid in the raster maps is $50 \times 50 \mathrm{~m}$ in size and the study area consists of 36,270 parcels in total.

Each thematic map in the database has its own class and criterion. These classes and criteria differ between 2 and 9. Land uses which are used in the preparation of maps and field surveys were used in the definition of classes and criteria. For the definition of each class and each criterion, pair-wise comparison technique was used. By this way, raw weights of each criterion for each land use were defined (Annex 1). These raw weights were standardized by using the formula suggested by Voogd (1983) and Malczewski (1999) as stated below.

$$
A_{j k}^{\prime}=\frac{A_{j k}-A_{k}^{\min }}{A_{k}^{\max }-A_{k}^{\min }},
$$

where $A_{j k}$ represents the raw score that is given by $k$ th criteria for $j$ th land-use type. According to this equation, standardized scores of each class in the thematic maps change between 0 and 1 and while unimportant classes get " 0 ", important classes get " 1 ".

\section{Results and Discussion}

As stated earlier, the aim of this study is to analyse the relation between the planners' different viewpoints and optimum land-use allocation. For that purpose, different data sets were formed for the weights assigned by each planner and then a mathematical programme (equations (3)-(6)) was run. Since the objective function in the model is a maximization, the programme assigns land uses which will maximize the benefit for each data set. The outputs of the mathematical model enabled us to analyse the results of the planner's different point of views.

Calculations were performed by using MATLAB, on Intel Core 2 Due 2.4 processor PC where each run took approximately $41 \mathrm{~min}$. 
Change in the total benefit according to planners' point of view is shown in Figure 3. As it is seen, the highest total benefit was observed in the third planner and the lowest in the fourth planner. The total benefit of the third planner was approximately twice as the total benefit of the fourth. When trade-off weights, criteria weights and land-use areas were analysed together with the total benefit values, the results were found to be very logical, exponible and consistent. Among the land uses, agriculture and forestation areas occupy the largest area. Those two land uses occupy $51 \%$ of the study area. The third planner assigned the highest trade-off weights to these areas and the lowest trade-off weights to residential development, commerce and administrative areas occupying only $3.2 \%$ of the total area. Therefore, since the third planner assigned to forestation and agricultural areas the highest trade-off weights, the suitability score of these land uses were found to be very high and as a result of programming, total benefit/objective was found to be the highest. On the contrary, the fourth planner assigned the highest trade-off weights to tourism and thermal tourism areas. Those two land uses occupy $10 \%$ of the total study area. The fourth planner assigned the lowest trade-off weights to forestation and agricultural areas. Thus, since the fourth planner assigned the highest trade-off weights to the land uses occupying the smallest area and lowest weights to land-use types occupying the largest area, the total benefit was found to be very low. Despite the fact that the second planner assigned a very high point to social benefit, thermal tourism and recreation areas were assigned the highest weights in total. Accordingly, total benefit decreased since the suitability score of land uses occupying the largest areas was lower than the third planner. As a result of these, we can say that there is a direct proportional relevance between the planner's total benefit and the size of land-use areas, planners' trade-off weights and combination weights of the selected criteria.

Another output of the model is the shadow price of each land use. The shadow price of each land use was shape-dependent on the trade-off weight of that land use, the weights of criteria and the size/demand of that land use (Figure 4). The highest shadow prices were found with the agriculture and forestation areas of the third planner and thermal tourism of the first planner. In residential development, commercial, public facilities and tourism, shadow prices of the first and the fourth planner were very high, whereas second and

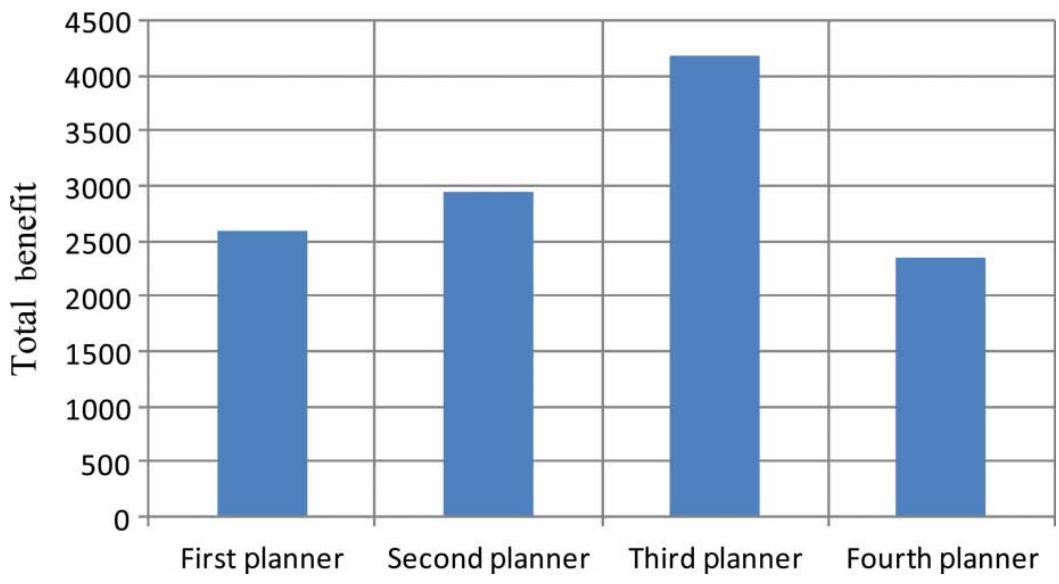

Figure 3. Change in the total benefit/objective function. 


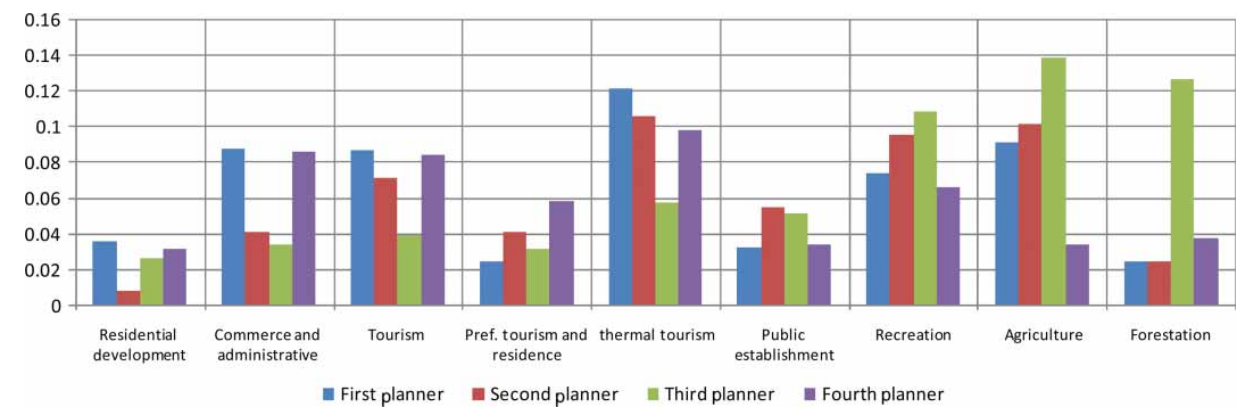

Figure 4. Shadow prices of each land use.

third planners got low shadow prices. On the other hand, in recreation, agriculture and public establishment areas, the shadow prices of the second and third planner were found to be very high and shadow prices of the first and the fourth planner were found to be low. Since the first, second and the fourth planner assigned to thermal tourism very high points, the shadow price of this land use was found to be very high in those planners. On the contrary, since the third planner assigned to the forestation area the highest trade-off weight, the shadow price of this land use was found to be very high. Consequently, we can state that there is a direct proportion between the shadow prices and trade-off weights but suitability scores and land-use demand were decisive. In other words, among the land uses having the same trade-off weights, a difference arose among the shadow prices. For example, whereas the first planner assigned the same trade-off weights to preferential tourism and public establishment, the shadow price of the public establishment was found higher. Similarly, despite the same planner assigned to forestation 0.08 and residential development 0.07 , the shadow price of residential development was found higher than forestation. This result shows that, despite the suitability score of residential development being high in some parcels, because there are less parcels devoted to the residential development, forestation was assigned to these parcels and if we decrease the number of parcels devoted to forestation and increase the number of parcels devoted to residential development, the total benefit will be higher.

The aim of the Generalized Assignment Model is to achieve the optimum land allocation that will maximize the benefit. Therefore, the model allocates one land-use type for each parcel. Model outputs showed that, criteria weights which reflect the planners' viewpoint affect the land-use allocation. In general, when the allocation of land uses was analysed, it was seen that (Figure 5); (1) the existing conservation scheme was very effective on the land-use allocation, and to the first-degree natural site conservation areas, forestation, recreation and agriculture were assigned; to the second-degree nature conservation areas, agriculture, recreation and forestation areas were assigned. However, especially to the part of the second-degree natural conservation areas in the southwest and northwest coasts of the study area, preferential tourism and residential and tourism land uses were assigned contrary to the decisions of the High Council of Conservation. Especially, since the third and fourth planner assigned close trade-off weights to tourism, preferential tourism and residential and residential areas, and the first planner assigned very high scores to tourism and residential areas in the site selection, preferential 


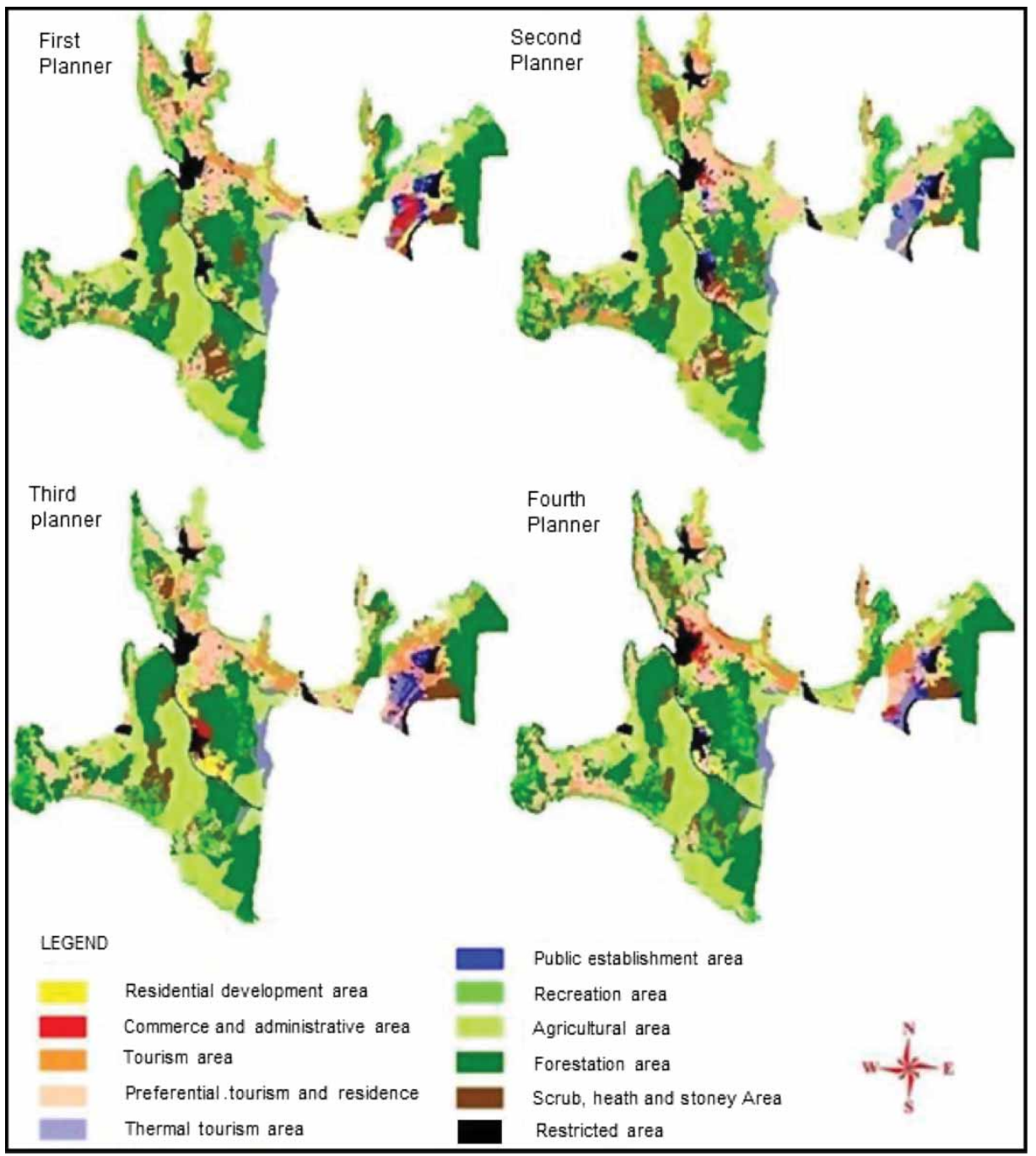

Figure 5. Optimum land use allocations by the mathematical programme.

tourism and residential and residential areas were assigned to second degree natural conservation areas. (2) According to the Coastal Law, within the first $100 \mathrm{~m}$ of the coastline construction is not allowed, in all optimum land-use schemes, the first part of the coastline was assigned to recreation, forestation and agriculture. (3) Since the site selection of agricultural areas is affected only by the quality of the soil and the existing land use, they were assigned as existing and protected agricultural areas in all schemes. (4) All of the forest areas and part of the first degree conservation areas were assigned as forestation areas. Assignment of other land uses showed differences depending on the weights given by the planners. (5) Residential development areas, commercial areas, administrative and public establishment areas were located separately in Ovacık and Reisdere settlements which are not inside the conservation area boundaries and around the Cesme city 
centre. But some differences emerged depending on the given weights. (6) Whereas thermal tourism was located on the area adjacent to the thermal spring in the first planner, according to some planners, thermal tourism was located in the areas close to the thermal source and according to the others it was located close to the Reisdere Settlement. Despite the thermal spring being on the fault line, the second, the third and the fourth planner assigned high scores to be distanced from the thermal source and fault line. (7) While the first and the second planner assigned to tourism a very high trade-off weight, they assigned a very low trade-off weight to preferential tourism and residential area. Therefore, tourism areas were located on the coastal zones close to the beach and just behind the coastline; preferential tourism and residential areas and residential areas were located on the inner parts. On the contrary, since the third and the fourth planner assigned close scores to tourism, preferential tourism and residential and residential areas, tourism areas were assigned to the area between the Cesme city centre and the Reisdere settlement, coastal areas in the west and east of the study area were assigned to preferential and residential tourism. As a result, despite that there were important differences between optimum land-use schemes, we can say that the results were similar to $1 / 25,000$ scale Land-Use Plan prepared in the year 2002.

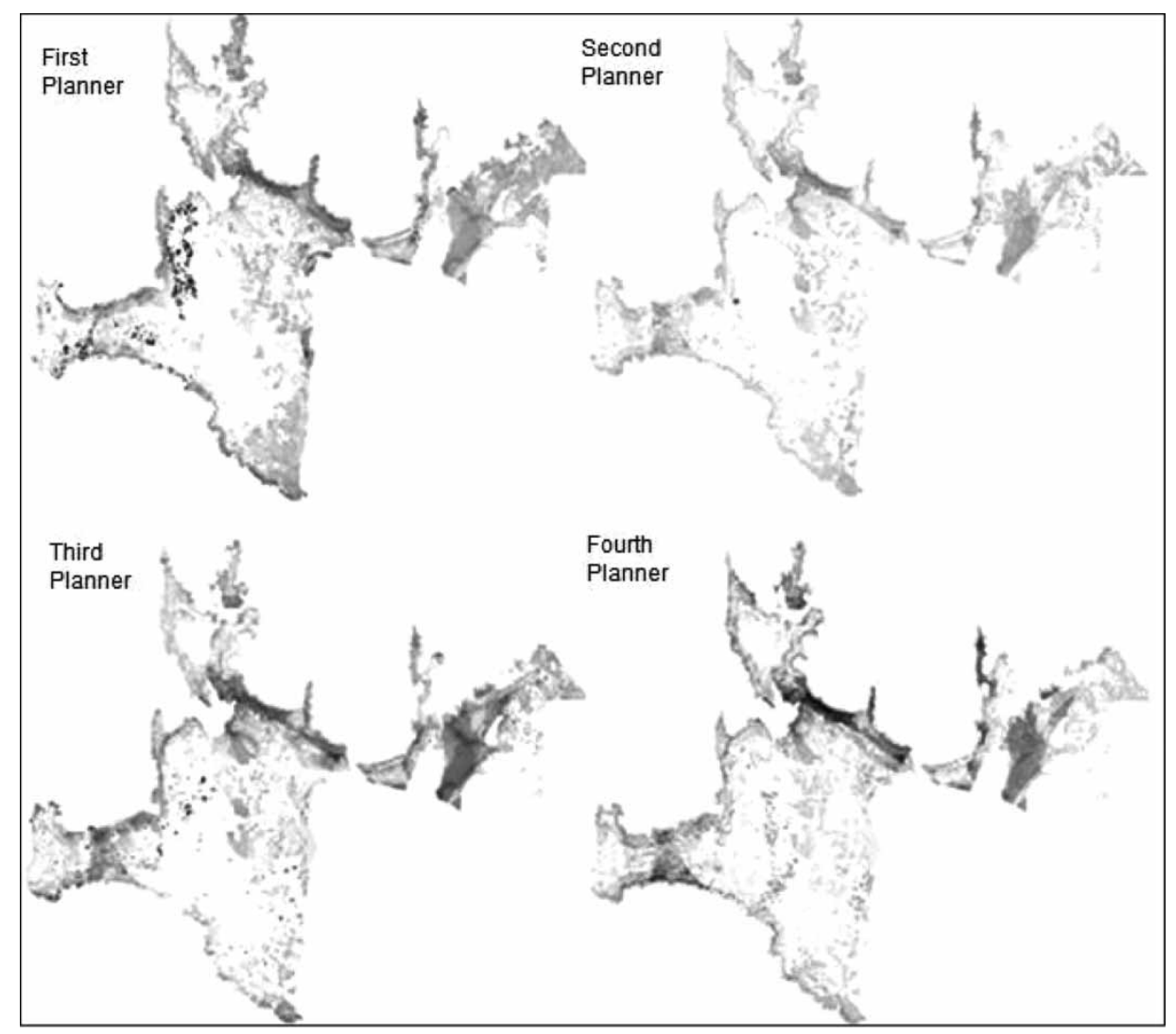

Figure 6. Spatial distribution of shadow prices (darker grey indicate a higher prices). 
Another output of the model was shadow prices of the parcels. Since the shadow prices were in the same interval, they could be compared with each other (Figure 6). Barr (1973) and Hanink and Cromley (1998) suggested that monetary value of each parcel could be calculated by using the proportion of the real price to the shadow price of the land uses by which market prices are known. Shadow prices of the second planner were found to be lower than the others. As expected, in all schemes, shadow price of parcels in which are close to the sea, beach, highway, second-degree roads and not in the conservation area were found to be higher, since they are attractive for most of the land uses. Whereas the shadow prices of parcels which were located on the inner parts were found to be very low. The shadow prices of the parcels on the neck located on the west of the study area were found to be very high because this area was not prone to earthquakes.

\section{Conclusion}

This empirical study showed that the Generalized Land Assignment model proposed by Hanink and Cromley (1998) integrated with the MCDM techniques could be used as an analytical tool for solving various planning problems. The model brought out objective discussion of the results of different scenarios by analysing the relation between planners' different viewpoints and the optimum land-uses allocation. However, while analysing the different scenarios, the following should be taken into consideration; there is a direct proportional relevance between the planner's total benefit and size of land-uses areas, planners' trade-off weights and combination weights of the selected criteria; and there is a direct proportion between the shadow prices and trade-off weights, but suitability scores and land-use demand were decisive. Despite the differences between optimum land-use schemes, the results were similar to the $1 / 25,000$ Scale Land Use Plan prepared in 2002. Therefore, the model outputs proved that the results were reasonable/logical and coherent. This solution was achieved generally in the context of MCDM techniques and specifically by using the mathematical programming.

To get a more realistic result, the selection of survey respondents should reflect a fair representation of the existing interest groups within the city at stake. In our study, due to time and budgetary constraints, we confined ourselves to a group of city planners for the surveys. Thus, the technique needs further confirmation with a more direct and fair participation of the interests groups.

Results of the model help planners and decision-makers to develop optimum alternatives which will provide development while protecting the environment. Besides, these results made it possible to evaluate the likely results of different alternatives and scenarios via changing the evaluation criteria of the planners and the trade-off weight. However, it should be kept in mind that the technique is very sensitive to the valuation to the respondents' interest. Moreover, in practice, the 1/25,000 Scale Land Use Plan study is a more complex study and the variables used in reality are much more in number.

The method applied in this study can easily be used in the analysis of various problems in daily planning practice. Especially, in the determination of the size of land allocation and in the redefinition of the standards for social and technical infrastructure areas, removal of the land-use allocation constraint will provide the amount of land that will be assigned for each land use. These boundary values will define the standards of social and technical infrastructure areas for that city. In this way, depending on the characteristic of each city, it will be possible to define different standards, because the value where the 
shadow price is zero defines a necessary amount of that land use in the optimum land-use distribution.

\section{References}

Aerts, J. C. J. H., Eisinger, E., Heuvelink, G. B. M. \& Stewart, T. J. (2003) Using linear integer programming for multi-site land-use allocation, Geographical Analysis, 35(2), pp. 148-169.

Aerts, J. C. J. H. \& Heuvelink, G. B. M. (2002) Using simulated annealing for resource allocation, International Journal of Geographical Information Science, 16(6), pp. 571-587.

Bammi, D. \& Bammi, D. (1979) Development of a comprehensive land use plan by means of a multiple objective mathematical programming model, Interface, 9(2), pp. 50-63.

Banai, R. (2005) Land resource sustainability for urban development: Spatial decision support system prototype, Environmental Management, 36(2), pp. 282-296.

Barr, J. L. (1973) Tiebout models of community structure, Papers of the Regional Science Association, 30(1), pp. 15-33.

Bodini, A. \& Giavelli, G. (1992) Multi-criteria analysis as a tool to investigate compatibility between conservation and development on Salina Island, Aeolian Archipelago, Italy, Environmental Management, 16(5), pp. 633-652.

Carver, S. (1991) Integrating multi-criteria evaluation with geographical information systems, International Journal of Geographical Information Systems, 5(3), pp. 321-339.

Çelik, H. M. \& Türk, E. (2011) Determination of optimum environmental conservation: Using multi-criteria decision-making techniques, European Planning Studies, 19(3), pp. 479-499.

Cheng, S., Chan, C. W. \& Huang, G. H. (2003) An integrated multi-criteria decision analysis and inexact mixed integer linear programming approach for solid waste management, Engineering Applications of Artificial Intelligence, $16(5-6)$, pp. 543-554.

Chuvieco, E. (1993) Integration of linear programming and GIS for land-use modeling, International Journal of Geographical Information Systems, 7(6), pp. 71-83.

Dai, F. C., Lee, C. F. \& Zhang, X. H. (2001) GIS-based geo-environmental evaluation for urban land-use planning: A case study, Engineering Geology, 61(4), pp. 257-271.

Dokmeci, V. F., Cagdas, G. \& Tokcan, S. (1993) Multiobjective land-use planning model, Journal of Urban Planning and Development, 119(1), pp. 15-22.

Eastman, J. R., Jin, W., Kyem, P. A. K. \& Toledano, J. (1995) Raster procedures for multi-criteria/multi-objective decisions, Photogrammetric Engineering \& Remote Sensing, 61(5), pp. 539-547.

Gabriel, S. A., Faria, J. A. \& Moglen, G. E. (2006) A multiobjective optimization approach to smart growth in land development, Socio-Economic Planning Sciences, 40(3), pp. 212-248.

Gilbert, K. C., Holmes, D. D. \& Rosenthal, R. E. (1985) A multiobjective discrete optimization model for land allocation, Management Science, 31(12), pp. 1509-1522.

Grabaum, R. \& Meyer, B. C. (1998) Multi-criteria optimization of landscape using GIS-based functional assessments, Landscape and Urban Planning, 43(1), pp. 21-34.

Hall, P. (Ed.) (1966) Von Thünen's Isolated State (Trans C. M. Wartenberg) (London: Pergamon Press).

Hanink, D. \& Cromley, R. G. (1998) Land-use allocation in the absence of complete market values, Journal of Regional Science, 38(3), pp. 465-480.

Joerin, F., Theriault, M. \& Musy, A. (2001) Using GIS and outranking multi-criteria analysis for land-use suitability assessment, International Journal of Geographical Information Science, 15(2), pp. 153-174.

Ligmann-Zielinska, A., Church, R. L. \& Jankowski, P. (2008) Spatial optimization as a generative technique for sustainable multiobjective land-use allocation, International Journal of Geographical Information Science, 22(6), pp. 601-622.

Malczewski, J. (1991) Central facility location and environmental health, Environment and Planning A, 23(3), pp. 385-395.

Malczewski, J. (1996) A GIS-based approach to multiple criteria group decision making, International Journal of Geographical Information Science, 10(8), pp. 955-971.

Malczewski, J. (1999) GIS and Multi-criteria Decision Analysis (New York: John Wiley).

Malczewski, J. (2006a) GIS-based multi-criteria decision analysis: A survey of the literature, International Journal of Geographical Information Science, 20(7), pp. 703-726. 
Malczewski, J. (2006b) Ordered weighted averaging with fuzzy quantifiers: GIS-based multi-criteria evaluation for land-use suitability analysis, International Journal of Applied Earth Observation and Geoinformation, 8(4), pp. 270-277.

Malczewski, J., Moreno-Sanchez, R., Bojorquez-Tapia, L. A. \& Ongay-Delhumeau, E. (1997) Multi-criteria group decision-making model for environmental conflict analysis in the Cape Region, Mexico, Journal of Environmental Planning and Management, 40(3), pp. 349-374.

Maniezzo, V., Mendes, I. \& Paruccini, M. (1998) Decision support for siting problems, Decision Support Systems, 23(3), pp. 273-284.

Minor, S. D. \& Jacobs, T. L. (1994) Optimal land allocation for solid- and hazardous- waste landfill sitting, Journal of Environmental Engineering, 120(5), pp. 1095-1108.

Natividade-Jesus, E., Coutinho-Rodrigues, J. \& Antunes, C. H. (2007) A multi-criteria decision support systems for housing evaluation, Decision Support Systems, 43(3), pp. 779-790.

Pereira, J. M. C. \& Duckstein, L. (1993) A multiple criteria decision-making approach to GIS-based land suitability evaluation, International Journal of Geographical Information Systems, 7(5), pp. 407-424.

Saaty, T. (1980) The Analytic Hierarchy Process (New York: McGraw-Hill).

Shirabe, T. (2005) A model of contiguity for spatial unit allocation, Geographical Analysis, 37(1), pp. 2-16.

Voogd, H. (1983) Multi-criteria Evaluation for Urban and Regional Planning (London: Pion Ltd).

Williams, J. C. (2003) Convex land acquisition with zero-one programming, Environment and Planning B: Planning and Design, 30(2), pp. 255-270.

Zucca, A., Sharifi, A. M. \& Fabbri, A. G. (2007) Application of spatial multi-criteria analysis to site selection for a local park: A case study in Bergamo Province, Italy, Journal of Environmental Management, 88(4), pp. 752-769. 
Annex 1. Standardized suitability scores for each land use and criteria

\begin{tabular}{|c|c|c|c|c|c|c|c|c|c|c|}
\hline Criteria & category & 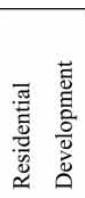 & 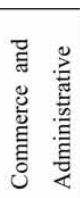 & 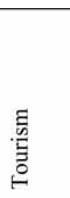 & 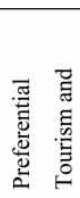 & 胥 & 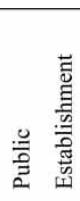 & 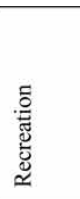 & 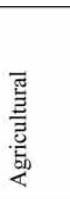 & 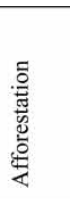 \\
\hline \multirow{5}{*}{$\begin{array}{l}\text { oे } \\
\frac{0}{0} \\
\frac{0}{n}\end{array}$} & $0-5$ & 1 & 1 & 1 & 1 & 1 & 1 & & & \\
\hline & $6-10$ & 0.710 & 0.294 & 0.710 & 0.710 & 0.710 & 0.710 & & & \\
\hline & $11-20$ & 0.077 & 0.111 & 0.077 & 0.077 & 0.077 & 0.077 & & & \\
\hline & $21-40$ & 0.022 & 0 & 0.022 & 0.022 & 0.022 & 0.022 & & & \\
\hline & $41-65$ & 0 & 0 & 0 & 0 & 0 & 0 & & & \\
\hline \multirow{6}{*}{ 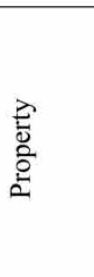 } & Private & 1 & 1 & 1 & 1 & 1 & 0.125 & 0 & & 0 \\
\hline & Municipality & 0.378 & 1 & 0.377 & 0.247 & 1 & 0.295 & 1 & & 0.098 \\
\hline & Treasury \& Municip. & 0.378 & 1 & 0.377 & 0.247 & 1 & 0.541 & 1 & & 0.156 \\
\hline & Deserted Land & 0.378 & 1 & 0.377 & 0.247 & 1 & 1 & 1 & & 0.234 \\
\hline & Treasury & 0.378 & 1 & 0.377 & 0.247 & 1 & 1 & 1 & & 0.234 \\
\hline & Forest & 0 & 0 & 0 & 0 & 0 & 0 & 0.302 & & 1 \\
\hline \multirow{5}{*}{ 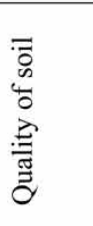 } & I \& II & 0 & 0 & 0 & 0 & 0 & 0 & 0 & 1 & 0 \\
\hline & III & 0 & 0.027 & 0 & 0 & 0 & 0 & 0 & 1 & 0 \\
\hline & IV & 0.208 & 0.147 & 0.159 & 0.207 & 0.207 & 0.207 & 0.231 & 0.428 & 0.190 \\
\hline & $\mathrm{V}$ & 0.652 & 0.339 & 0.545 & 0.648 & 0.648 & 0.648 & 0.498 & 0.119 & 0.476 \\
\hline & VI \&VII & 1 & 1 & 1 & 1 & 1 & 1 & 1 & 0 & 1 \\
\hline \multirow{7}{*}{ 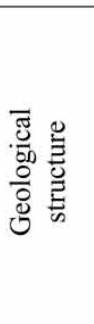 } & Agglomerate & 1 & 1 & 1 & 1 & 1 & 1 & & & \\
\hline & Agglomerate \&Tuff & 1 & 1 & 1 & 1 & 1 & 1 & & & \\
\hline & Limestone & 0.531 & 0.531 & 0.531 & 0.531 & 0.531 & 0.531 & & & \\
\hline & Dolomite & 0.303 & 0.303 & 0.303 & 0.303 & 0.303 & 0.303 & & & \\
\hline & Clay limestone marl & 0.155 & 0.155 & 0.155 & 0.155 & 0.155 & 0.155 & & & \\
\hline & Alluvium & 0.040 & 0.040 & 0.040 & 0.040 & 0.040 & 0.040 & & & \\
\hline & Talus & 0 & 0 & 0 & 0 & 0 & 0 & & & \\
\hline \multirow{7}{*}{ 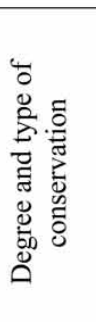 } & $1^{\text {st }}$ Natural & 0 & 0 & 0 & 0 & 0 & 0 & 1 & & 1 \\
\hline & $2^{\text {nd }}$ Natural & 0 & 0 & 0.187 & 0.187 & 0.215 & 0 & 1 & & 0.698 \\
\hline & $3^{\text {rd }}$ Natural & 0.216 & 0.216 & 0.456 & 0.456 & 0.504 & 0.216 & 1 & & 0.284 \\
\hline & $1^{\text {st }}$ Archaeological & 0 & 0 & 0 & 0 & 0 & 0 & 0 & & 0 \\
\hline & $3^{\text {rd }}$ Archaeological & 0.229 & 0.226 & 0.477 & 0.477 & 0.533 & 0.229 & 1 & & 0.254 \\
\hline & Urban Cons. Area & 0.394 & 0.339 & 0.456 & 0.456 & 0.041 & 0.394 & 1 & & 0 \\
\hline & Not conserved Area & 1 & 1 & 1 & 1 & 1 & 1 & 1 & & 0.355 \\
\hline
\end{tabular}

(Continued.) 
Annex 1. Continued

\begin{tabular}{|c|c|c|c|c|c|c|c|c|c|c|}
\hline \multirow{4}{*}{ 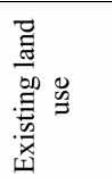 } & Unsuitable land & 1 & 1 & 1 & 1 & 1 & 1 & 1 & 0.250 & 0.318 \\
\hline & Forest & 0 & 0 & 0 & 0 & 0 & 0 & 0.200 & 0 & 1 \\
\hline & Agriculture & 0.332 & 0.282 & 0.282 & 0.283 & 0.155 & 0.268 & 0.200 & 0 & 0.079 \\
\hline & Others & 0.332 & 0.229 & 0.229 & 0.099 & 0.392 & 0.219 & 0 & 1 & 0 \\
\hline \multirow{4}{*}{$\begin{array}{l}\text { गू } \\
\text { कू } \\
\frac{0}{4}\end{array}$} & North & 0 & & 0 & 0 & 0 & & 1 & & \\
\hline & West & 0.348 & & 0.348 & 0.348 & 0.348 & & 0 & & \\
\hline & East & 0.348 & & 0.348 & 0.348 & 0.348 & & 0 & & \\
\hline & South & 1 & & 1 & 1 & 1 & & 1 & & \\
\hline \multirow{2}{*}{ 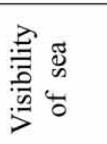 } & Yes & 1 & & 1 & 1 & & & 1 & & \\
\hline & No & 0 & & 0 & 0 & & & 0 & & \\
\hline \multirow{4}{*}{ 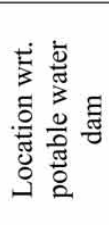 } & First degree & 0 & 0 & 0 & 0 & 0 & 0 & 0 & & \\
\hline & second degree & 0 & 0 & 0 & 0 & 0 & 0 & 0 & & \\
\hline & third degree & 0 & 0 & 0 & 0 & 0 & 0 & 0.442 & & \\
\hline & $\begin{array}{l}\text { Out of protection belt } \\
\text { of dam }\end{array}$ & 1 & 1 & 1 & 1 & 1 & 1 & 1 & & \\
\hline \multirow{6}{*}{ 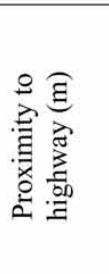 } & $0-100$ & 1 & 1 & 1 & 0.504 & & 1 & & & \\
\hline & $101-250$ & 0.509 & 0.367 & 0.730 & 1 & & 0.580 & & & \\
\hline & $251-500$ & 0.230 & 0.171 & 0.339 & 0.546 & & 0.312 & & & \\
\hline & $501-1000$ & 0.079 & 0.072 & 0.116 & 0.162 & & 0.147 & & & \\
\hline & $1001-2000$ & 0.029 & 0 & 0.041 & 0.050 & & 0.050 & & & \\
\hline & $2000+$ & 0 & 0 & 0 & 0 & & 0 & & & \\
\hline \multirow{6}{*}{ 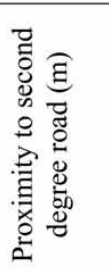 } & $0-100$ & 1 & 1 & 1 & 1 & 1 & 1 & & & \\
\hline & $101-250$ & 0.396 & 0.367 & 0.564 & 0.396 & 0.367 & 0.580 & & & \\
\hline & $251-500$ & 0.214 & 0.171 & 0.312 & 0.214 & 0.171 & 0.312 & & & \\
\hline & $501-1000$ & 0.102 & 0.069 & 0.144 & 0.102 & 0.069 & 0.147 & & & \\
\hline & $1001-2000$ & 0.037 & 0.002 & 0.052 & 0.037 & 0.002 & 0.050 & & & \\
\hline & $2000+$ & 0 & 0 & 0 & 0 & 0 & 0 & & & \\
\hline \multirow{5}{*}{ 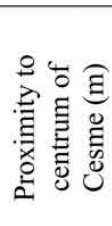 } & $0-1000$ & 1 & 1 & & 1 & & 1 & & & \\
\hline & $1001-1500$ & 0.349 & 0.534 & & 0.349 & & 0.537 & & & \\
\hline & $1501-2000$ & 0.165 & 0.254 & & 0.165 & & 0.262 & & & \\
\hline & $2001-3000$ & 0.082 & 0.094 & & 0.082 & & 0.122 & & & \\
\hline & $3000+$ & 0 & 0 & & 0 & & 0 & & & \\
\hline \multirow{5}{*}{ 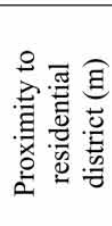 } & $0-250$ & 1 & 1 & & & & 1 & & & \\
\hline & $251-500$ & 0.349 & 0.365 & & & & 0.349 & & & \\
\hline & $501-1000$ & 0.165 & 0.178 & & & & 0.165 & & & \\
\hline & $1001-2000$ & 0.082 & 0.064 & & & & 0.082 & & & \\
\hline & $2000+$ & 0 & 0 & & & & 0 & & & \\
\hline
\end{tabular}

(Continued.) 
Annex 1. Continued

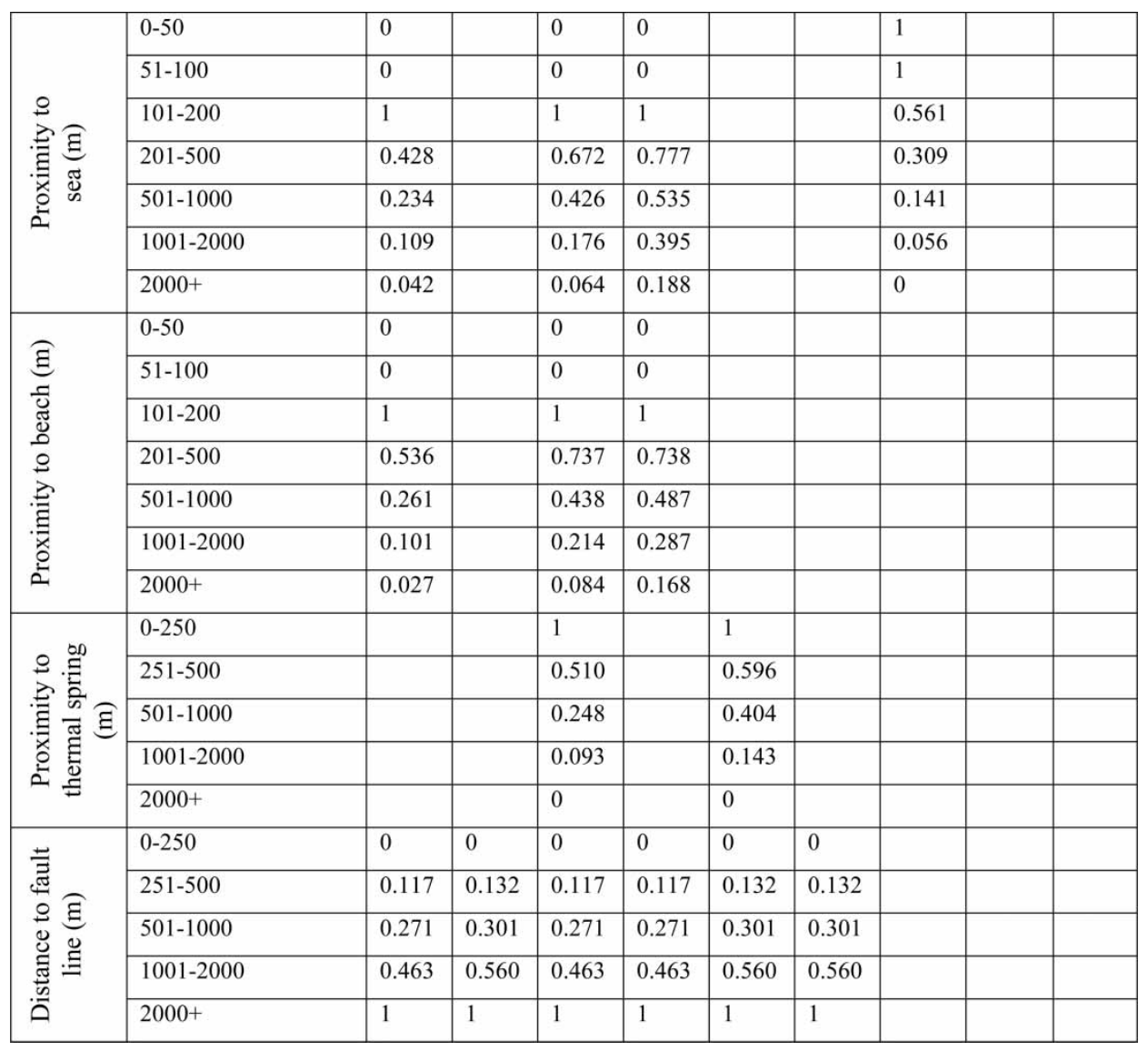


Annex 2. Combination weights of the selected criteria

\begin{tabular}{|c|c|c|c|c|c|c|c|c|c|c|c|c|c|c|c|c|c|c|c|c|c|c|c|c|c|c|c|c|c|c|c|c|c|c|c|c|c|c|c|c|}
\hline \multirow[b]{2}{*}{$\begin{array}{l}\text { Criteria/ } \\
\text { Planner }\end{array}$} & \multicolumn{5}{|c|}{$\begin{array}{c}\text { Residential } \\
\text { Development }\end{array}$} & \multicolumn{4}{|c|}{$\begin{array}{l}\text { Commerce and } \\
\text { Administrative }\end{array}$} & \multicolumn{5}{|c|}{ Tourism } & \multicolumn{4}{|c|}{\begin{tabular}{|c|}
$\begin{array}{c}\text { Pref. Tourism and } \\
\text { Residential }\end{array}$ \\
\end{tabular}} & \multicolumn{5}{|c|}{ Thermal Tourism } & \multicolumn{4}{|c|}{$\begin{array}{c}\text { Public } \\
\text { Establishment }\end{array}$} & \multicolumn{5}{|c|}{ Recreation } & \multicolumn{4}{|c|}{ Agricultural } & \multicolumn{4}{|c|}{ Forestation } \\
\hline & & & & & & 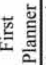 & & & & & & & & & 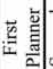 & & & & & & & & & 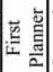 & & & & $\overrightarrow{\frac{2}{2}}$ & & & & & t. & & & & & & & \\
\hline Slope & 0.02 | & 0.0 & 0 & & 0.033 & 0.03 & 0.02 & $\mid 0.03$ & 0.02 & 0.01 & 0.0 & $\begin{array}{l}1 \\
0 .\end{array}$ & & 0.022 & 0.02 & 0.03 & 0.02 & 0.02 & 0.04 & 40.0 & 12 & & 0.02 & \begin{tabular}{|l|}
0.02 \\
\end{tabular} & $0.02 \mid$ & 0.02 & 0.02 & & & & & & & & & & & & & \\
\hline $\begin{array}{l}\text { Property } \\
\end{array}$ & 0.05 & 0.0 & $\begin{array}{lll}1 & 0 . \\
\end{array}$ & & 0.01 & 0.01 & 0.01 & 0.01 & 0.05 & 0.01 & 0.0 & $\begin{array}{lll}1 & 0 . \\
\end{array}$ & 01 & 0.01 & 0.06 & 0.01 & 0.06 & 0.01 & 0.04 & 4.0 & \begin{tabular}{l|l}
01 & 0.4 \\
\end{tabular} & & 0.01 & \begin{tabular}{|l|l}
0.06 \\
\end{tabular} & 0.06 & 0.11 & 0.07 & 0.09 & 0.1 & \begin{tabular}{l|l}
14 & 0. \\
.
\end{tabular} & .05 & 0.05 & & & & & 0.61 & $\begin{array}{l}10.73 \\
0.73\end{array}$ & 0.13 & 0.13 \\
\hline Quality of Soil & 0.08 & 0.1 & 0. & & 0.12 & 0.08 & 0.14 & 0.11 & 0.1 & 0.04 & 0. & & 080 & 0.08 & 0.06 & 0.11 & 0.09 & 0.08 & 0.04 & 0 & \begin{tabular}{l|l}
.1 & 0.1 \\
\end{tabular} & & 0.11 & 0.06 & 0.12 & 0.06 & 0.1 & 0.03 & $\begin{array}{l}3.0 .8 \\
0.8\end{array}$ & $\begin{array}{ll}05 & 0 . \\
.\end{array}$ & .050 & 0.02 & 0.83 & 0.9 & 0.75 & 0.8 & 0.12 & $\begin{array}{ll}2 & 0.09 \\
\end{array}$ & 0.52 & 0.38 \\
\hline \begin{tabular}{|l} 
Geelogical \\
Structure
\end{tabular} & 0.08 & 0.0 & 0. & & 0.08 & 0.08 & 0.02 & 0.08 & 0.1 & 0.04 & 0.0 & 1.0. & & 0.08 & 0.1 & 0.03 & 0.06 & 0.07 & 0.11 & 0.0 & \begin{tabular}{l|l}
12 & 0.1 \\
0.1
\end{tabular} & & 0.11 & 0.12 & \begin{tabular}{l|l}
0.02 \\
\end{tabular} & 0.11 & 0.09 & & & & & & & & & & & & & \\
\hline \begin{tabular}{|l} 
Conservati \\
Degree
\end{tabular} & 0.12 & 0.1 & 0 & & 0.12 & 0.16 & 0.14 & 0.16 & 0.1 & 0.12 & 0. & 10 & & 0.13 & 0.1 & 0.17 & 0.13 & 0.11 & 0.11 & 0.1 & 180.4 & & 0.11 & 0.12 & 0.15 & 0.11 & 0.14 & 0.22 & 20.3 & $\begin{array}{ll}39 & 0 .\end{array}$ & 25.0 & 0.16 & & & & & 0.21 & $\begin{array}{l}\mid 0.09 \\
\end{array}$ & 0.32 & \begin{tabular}{l|l}
2 & 0.38 \\
\end{tabular} \\
\hline \begin{tabular}{l|} 
Existing Land \\
Use
\end{tabular} & 0.05 & 0.0 & 0. & & 0.01 & 0.01 & 0.02 & 0.01 & 0.05 & 0.04 & 0.0 & \begin{tabular}{l|l}
2 & 0. \\
\end{tabular} & & 0.01 & 0.01 & 0.01 & 0.02 & 0.01 & 0.04 & 0.0 & $\begin{array}{ll}22 & 0.4 \\
\end{array}$ & & 0.01 & 0.06 & 0.02 & 0.02 & 0.01 & 0.22 & 0.0 & \begin{tabular}{l|l}
05 & 0.
\end{tabular} & $.02{ }^{\circ}$ & 0.02 & \begin{tabular}{|l|}
0.17 \\
\end{tabular} & 0.1 & 0.25 & 0.1 & 0.07 & 70.09 & 0.04 & \begin{tabular}{l|l}
4 & 0.13 \\
\end{tabular} \\
\hline Aspect & 0.05 & 0.0 & 0. & & 0.01 & & & & & 0.04 & 0.0 & $\begin{array}{lll}4 & 0 \\
\end{array}$ & & 0.05 & 0.01 & 0.01 & 0.01 & 0.06 & 0.04 & 0.0 & $\begin{array}{ll}12 & 0.4 \\
\end{array}$ & & 0.07 & & & & & 0.02 & 0.1 & \begin{tabular}{l|l}
14 & 0. \\
\end{tabular} & .150 & 0.26 & & & & & & & & \\
\hline Visibility of Sea & 0.01 & 0.0 & 0 & & 0.01 & & & & & 0.07 & 0. & \begin{tabular}{l|l}
1 & 0. \\
\end{tabular} & & 0.05 & 0.1 & 0.03 & 0.06 & 0.06 & & & & & & & & & & 0.02 & 0.0 & $\begin{array}{ll}05 & 0 . \\
\end{array}$ & 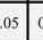 & 0.16 & & & & & & & & \\
\hline $\begin{array}{l}\text { Location wrt. } \\
\text { potable water } \\
\text { dam }\end{array}$ & 0.05 & 0.1 & 0 & & 0.12 & 0.12 & 0.14 & 0.11 & 0.1 & 0.12 & 0. & & & 0.08 & 0.06 & 0.11 & 0.08 & 0.09 & 0.11 & 0.1 & 120.1 & & 0.07 & 0.06 & 0.12 & 0.06 & 0.06 & 0.22 & 0.0 & & 2.250 & 0.16 & & & & & & & & \\
\hline $\begin{array}{l}\text { Proximity to } \\
\text { Highway }\end{array}$ & 0.02 & 0.0 & 0 & & 0.05 & 0.1 & 0.02 & 0.06 & 0.06 & 0.02 & 0.0 & 0 & & 0.03 & 0.02 & 0.01 & 0.03 & 0.03 & & & & & & 0.05 & 0.04 & 0.05 & 0.04 & & & & & & & & & & & & & \\
\hline \begin{tabular}{|l|}
$\begin{array}{l}\text { Proximity to } \\
\text { second Degree } \\
\text { Road }\end{array}$ \\
\end{tabular} & 0.07 & 0.0 & 0. & & 0.02 & 0.03 & 0.02 & 0.02 & 0.02 & 0.02 & 0.0 & $\begin{array}{l}1 \\
\end{array}$ & & 0.01 & 0.06 & 0.07 & 0.09 & 0.01 & 0.04 & 0.0 & $33^{0 .}$ & & 0.04 & 0.02 & 0.01 & 0.05 & 0.01 & & & & & & & & & & & & & \\
\hline $\begin{array}{l}\text { Proximity to city } \\
\text { centre of Cesme }\end{array}$ & 0.07 & 0.1 & 0. & & 0.16 & 0.03 & 0.16 & 0.02 & 0.2 & & & & & & 0.06 & 0.07 & 0.03 & 0.08 & & & & & & 0.15 & 0.12 & 0.02 & 0.17 & & & & & & & & & & & & & \\
\hline $\begin{array}{l}\text { Proximity to } \\
\text { Residential } \\
\text { District }\end{array}$ & 0.13 & 0.0 & 0. & & 0.02 & 0.03 & 0.16 & 0.16 & 0.02 & & & & & & & & & & & & & & & 0.15 & 0.15 & 0.15 & 0.1 & & & & & & & & & & & & & \\
\hline Proximity to Sea & 0.07 & 0.0 & 20. & & 0.02 & & & & & 0.14 & 0.1 & & & 0.13 & 0.11 & 0.12 & 0.09 & 0.13 & & & & & & & & & & 0.17 & 0.1 & 170. & .17 & 0.17 & & & & & & & & \\
\hline $\begin{array}{l}\text { Proximity to } \\
\text { Beach }\end{array}$ & 0.02 & 0.0 & & & 0.02 & & & & & 0.22 & 0.1 & & & 0.13 & 0.16 & 0.12 & 0.09 & 0.13 & & & & & & & & & & & & & & & & & & & & & & \\
\hline & & & & & & & & & & 0.02 & 0.0 & 10 & & 0.08 & & & & & 0.35 & 0.2 & 23. & & 0.3 & & & & & & & & & & & & & & & & & \\
\hline $\begin{array}{l}\text { Distance to Fault } \\
\text { Line }\end{array}$ & 0.13 & 0.1 & 0 & 16 & 1.21 & 0.3 & 0.15 & 0.24 & 0.2 & 0.07 & 0.1 & 0 & & 0.13 & 0.1 & 0.12 & 0.17 & 0.13 & 0.12 & 0.2 & 250. & & 0.17 & 0.15 & 0.19 & 0.24 & 0.17 & & & & & & & & & & & & & \\
\hline Sum & 1 & 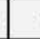 & & 1 & 1 & 1 & 1 & 1 & 1 & 1 & 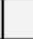 & & 1 & 1 & 1 & 1 & 1 & 1 & 1 & & 1 & & 1 & 1 & 1 & 1 & 1 & 1 & & & 1 & & & & & & & & 1 & 1 \\
\hline
\end{tabular}

